\title{
Phytoplankton diversity of two floodplain lakes (pats) of Manipur, northeastern India
}

\author{
B.K. Sharma \\ Department of Zoology, North-Eastern Hill University, Permanent campus, Umshing, Shillong, Meghalaya 793022, India \\ Email:bksharma@nehu.ac.in
}

Date of publication (online): 26 October 2010 Date of publication (print): 26 October 2010 ISSN 0974-7907 (online) I 0974-7893 (print)

Editor: K.K. Sharma

\section{Manuscript details:}

Ms \# 02427

Received 24 March 2010

Final received 17 August 2010

Finally accepted 10 September 2010

Citation: Sharma, B.K. (2010). Phytoplankton diversity of two floodplain lakes (pats) of Manipur, northeastern India. Journal of Threatened Taxa 2(11): 1273-1281.

Copyright: (C) B.K. Sharma 2010. Creative Commons Attribution 3.0 Unported License. JoTT allows unrestricted use of this article in any medium for non-profit purposes, reproduction and distribution by providing adequate credit to the authors and the source of publication.

Author Details: B.K. Sharma is a Professor in Department of Zoology and Dean, School of Life Sciences and is a specialist in the fields of limnology and acquatic biodiversity

Acknowledgements: The author is thankful to the G. B. Pant Institute of Himalayan Environmental Development, Almora for a research grant during which the field work for this study was undertaken. Thanks are due to the Head, Department of Zoology, NorthEastern Hill University, Shillong for necessary laboratory facilities.
Abstract: Phytoplankton communities of Utra and Waithou pats (floodplain lakes) of Manipur, studied during November 2002 - October 2004, revealed 62 and 61 species, and indicated monthly richness between 27-45 (38 \pm 4$)$ and 32-46 (39 \pm 4$)$ species respectively with distinct qualitative importance of Chlorophyta $(29 \pm 4$ and $28 \pm 3$ species). Phytoplankton (154 $\pm 31 \mathrm{n} / \mathrm{l}$ and $164 \pm 34 \mathrm{n} / \mathrm{l})$ comprised between $43.8 \pm$ $3.0 \%$ and $41.5 \pm 3.0 \%$ of net plankton abundance respectively of these two lakes. Chlorophyta $(115 \pm 23 \mathrm{n} / \mathrm{l}$ and $113 \pm 21 \mathrm{n} / \mathrm{l})$, the dominant quantitative component $(74.4$ $\pm 4.1 \%$ and $67.5 \pm 4.8 \%$ ), indicated importance of the demids. Bacillariophyta $(33 \pm$ $9 \mathrm{n} / \mathrm{l}$ and $37 \pm 12 \mathrm{n} / \mathrm{l}$ ) formed sub-dominant group, and Dinophyta > Euglenophyta > Chrysophyta showed very low densities. Various abiotic factors registered relatively limited influence on richness and abundance of phytoplankton as well as on abundance of individual groups in Utra Pat than in Waithou Pat. Multiple regression depicted higher cumulative influence of fifteen abiotic factors on the stated biotic parameters in these pats. Both richness and abundance of Phytoplankton recorded significant monthly variations, showed insignificant temporal variations between two lakes and followed indefinite annual patterns in each pat. Phytoplankton communities of the sampled pats are characterized by higher species diversity, higher evenness and lower dominance.

Keywords: Abundance, ecology, floodplain lakes, Manipur, phytoplankton, richness.

\section{INTRODUCTION}

The floodplain lakes form an important component of inland aquatic resources of northeastern India, exhibit significant fishery potential and are mainly located in the states of Assam and Manipur. Little is known so far about biological productivity of these interesting ecotones in general and about composition, abundance and ecology of phytoplankton in particular. The related works from northeastern India are confined to preliminary reports (Yadava et al. 1987; Goswami \& Goswami 2001) from certain floodplain lakes ('beels') of Assam while Sharma (2004) initiated detailed analysis of phytoplankton of a beel of upper Assam and Sharma (2010) studied their ecology in Deepor beel (a Ramsar site). On the contrary, the studies in the floodplain lakes ('pats') of Manipur refer to a recent contribution (Sharma 2009) on phytoplankton diversity of Loktak Lake (a Ramsar site).

The present study on composition and synecology of phytoplankton of two floodplain lakes (pats) of Manipur, therefore, assumes limnological importance in view of the stated lacunae. The observations are made on monthly variations of richness and abundance of phytoplankton and their constituent groups as well as on their community similarities, species diversity, dominance and evenness. Remarks are made on the influence of abiotic factors on temporal variations in richness and abundance of phytoplankton.

\section{MATERIALS AND METHODS}

The present study results from limnological investigations undertaken, during November 2002 - October 2004, in two floodplain lakes (commonly

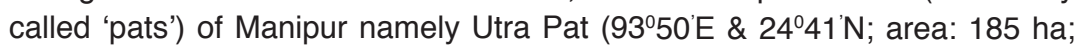


max. depth: $2.2 \mathrm{~m}$, mean depth: $1.4 \mathrm{~m}$; altitude: $783 \mathrm{~m}$, Bishnupur District) and Waithou Pat (93055'E \& $24^{\circ} 41^{\prime} \mathrm{N}$; area: 455ha; max. depth: $1.7 \mathrm{~m}$, mean depth: $1.2 \mathrm{~m}$; altitude: $785 \mathrm{~m}$, Thoubal District). The common aquatic plants of these wetlands included Eichhornia crassipes, Hydrilla verticellata, Euryale ferox, Utricularia flexuosa, Trapa natans, Lemna trisula, Pistia striates, Salvinia, Nymphaea spp., Nymphoides spp., Nelumbo mucifera, Azolla pinnata, and Sagittaria sp.

Water samples were collected monthly from Utra and Waithou pats during November 2002 - October 2004; water temperature, specific conductivity, $\mathrm{pH}$ and dissolved oxygen were recorded by the field probes while other abiotic factors were analyzed following APHA (1992). Monthly qualitative and quantitative plankton samples were collected from two floodplain lakes by nylobolt plankton net (No. 25) and were preserved in 5\% formalin. The former were screened and phytoplankton taxa were identified following Needham \& Needham (1962), Islam \& Haroon (1980), Adoni et al. (1985), Fitter \& Manuel (1986) and several individual research papers. Quantitative plankton samples were analyzed with a Sedgwick-Rafter counting cell for abundance $(n / l)$ of phytoplankton and constituent groups.

Community similarities (Sorenson's index), species diversity (Shannon's index), dominance (Berger-Parker's index) and evenness (Pileou's index) were calculated following Ludwig \& Reynolds (1988) and Magurran (1988). Two-way ANOVA was used to analyse the significance of temporal variation of the biotic communities. Ecological relationships between abiotic and biotic parameters in Utra and Waithou pats were determined by simple correlation coefficients $\left(r_{1} \& r_{2}\right.$ respectively), and their $p$ values were calculated following http://faculty.vassar.edu/ lowry/tabs.html. Multiple regressions $\left(R_{1}{ }^{2} \& R_{2}{ }^{2}\right)$ were used to ascertain cumulative effect of 15 abiotic factors (water temperature, rainfall, $\mathrm{pH}$, specific conductivity, dissolved oxygen, free carbon dioxide, alkalinity, hardness, phosphate, nitrate, sulphate, silicate, chloride, dissolved organic matter and total dissolved solids) on phytoplankton and their groups in each pat respectively.

\section{RESULTS AND DISCUSSION}

Abiotic parameters: Water temperature affirms sub-tropical nature of Utra and Waithou pats. Both the floodplain lakes are characterized by slightly acidic, soft and 'Calcium-poor' waters which depict moderate dissolved oxygen, low free $\mathrm{CO}_{2}$, low concentration of micro-nutrients and other abiotic factors (Table 1). Specific conductivity exhibits low ionic concentrations of

Table 1. Abiotic factors of Utra Pat and Waithou Pat (November 2002- October 2004)

\begin{tabular}{|c|c|c|c|c|}
\hline \multirow[t]{2}{*}{ Factors $\downarrow$} & \multicolumn{2}{|c|}{ Utra Pat } & \multicolumn{2}{|c|}{ Waithou Pat } \\
\hline & Range & Mean \pm SD & Range & Mean \pm SD \\
\hline Air Temperature & $16.4-29.4$ & $23.8 \pm 3.8$ & $12.4-31.4$ & $23.3 \pm 4.8$ \\
\hline Water Temperature $\quad{ }^{\circ} \mathrm{C}$ & $16.2-27.9$ & $22.2 \pm 3.5$ & $10.5-29.2$ & $21.6 \pm 4.8$ \\
\hline Rainfall & $0-480.0$ & $138.2 \pm 154.8$ & $0-480.0$ & $138.2 \pm 154.8$ \\
\hline $\mathrm{pH}$ & $5.40-6.68$ & $6.23 \pm 0.32$ & $5.59-6.60$ & $6.21 \pm 0.28$ \\
\hline Sp. Conductivity $\mu \mathrm{S} / \mathrm{cm}$ & $48.0-120.5$ & $77.2 \pm 21.6$ & $52.0-120.5$ & $92.3 \pm 16.8$ \\
\hline Dissolved Oxygen mg/l & $4.0-10.0$ & $6.0 \pm 1.4$ & $2.4-12.0$ & $5.3 \pm 1.8$ \\
\hline Free $\mathrm{CO}_{2}$ & $6.0-18.2$ & $8.7 \pm 3.6$ & $6.0-20.0$ & $13.7 \pm 4.1$ \\
\hline Alkalinity & $10.0-44.0$ & $19.5 \pm 9.4$ & $10.0-36.2$ & $19.7 \pm 5.6$ \\
\hline Hardness & $20.0-46.0$ & $33.0 \pm 7.4$ & $20.1-56.0$ & $33.6 \pm 7.8$ \\
\hline Calcium & $4.2-14.7$ & $7.8 \pm 2.1$ & $6.3-15.2$ & $10.9 \pm 2.6$ \\
\hline Magnesium & $2.0-8.7$ & $5.0 \pm 1.5$ & $2.0-9.6$ & $5.5 \pm 2.1$ \\
\hline Sodium & $1.2-8.8$ & $5.9 \pm 1.9$ & $1.0-9.4$ & $6.4 \pm 2.0$ \\
\hline Potassium & $3.2-9.4$ & $6.0 \pm 1.6$ & $4.0-9.8$ & $6.7 \pm 1.9$ \\
\hline Phosphate & $0.07-0.28$ & $0.19 \pm 0.06$ & $0.09-0.46$ & $0.23 \pm 0.08$ \\
\hline Nitrate & $0.25-0.41$ & $0.34 \pm 0.04$ & $0.23-0.39$ & $0.33 \pm 0.05$ \\
\hline Sulphate & $0.61-0.96$ & $0.82 \pm 0.10$ & $0.48-0.94$ & $0.84 \pm 0.10$ \\
\hline Silicate & $6.4-9.2$ & $8.3 \pm 0.8$ & $5.12-12.15$ & $9.1 \pm 1.5$ \\
\hline Chloride & $14.12-24.9$ & $17.4 \pm 2.6$ & $9.5-21.1$ & $14.6 \pm 3.9$ \\
\hline DOM & $0.45-1.0$ & $0.77 \pm 0.12$ & $0.11-1.05$ & $0.58 \pm 0.32$ \\
\hline TDS & $0.31-0.92$ & $0.57 \pm 0.21$ & $0.28-0.71$ & $0.45 \pm 0.14$ \\
\hline
\end{tabular}


the sampled lakes; this interesting feature warrants their inclusion under 'Class l' category of trophic classification vide Talling \& Talling (1965). In general, the recorded ranges of various abiotic parameters broadly concur with the results of Loktak Lake (Sharma 2009).

Phytoplankton composition, richness and similarities: Total 79 species, belonging to five groups, documented in this study indicate fairly speciose and diverse nature of phytoplankton in general as well as of Utra Pat (62 species) and Waithou Pat (61 species) in particular (Tables $2 \& 3$ ). Overall richness compares well with the author's report of 75 species (Sharma 2009) from Loktak Lake (a Ramsar site) of Manipur. Richness in individual pats is marginally higher than 59 species from Deepor Beel - another Ramsar site (Sharma 2010) but outnumbers distinctly the reports from the floodplains of
Bihar (Baruah et al. 1993, Sanjer \& Sharma 1995) and Assam (Sharma 2004). Phytoplankton communities show $73.2 \%$ similarity (vide Sorenson's index) between Utra and Waithou pats, thereby, reflecting certain degree of variations in their species composition while 94.9 and $94.2 \%$ similarities noticed in the sampled pats respectively indicate little annual differences in their community structure individually.

Chlorophyta (61 species), the most speciose group, include 48 and 47 species in Utra and Waithou pats respectively (Tables $2 \& 3$ ) with qualitative importance of the desmid genera namely Closterium $>$ Cosmarium $>$ Micrasterias $>$ Gonatozygon $=$ Xanthidium $=$ Pleurotaenium in both the pats while Staurastrum shows more richness in Utra Pat (8 species) than in Waithou Pat (3 species). In general, qualitative importance of the green algae

Table 2. Temporal variations of phytoplankton at Utra Pat

\begin{tabular}{|c|c|c|c|c|c|}
\hline Parameters $\downarrow$ & Years $\rightarrow$ & \multicolumn{2}{|c|}{ 2002-03 } & \multicolumn{2}{|c|}{ 2003-2004 } \\
\hline Qualitative & & \multicolumn{4}{|c|}{ Chlorophyta $>$ Bacillariophyta $>$ Dinophyta $=$ Euglenophyta $>$ Chrysophyta } \\
\hline Phytoplankton & Total & \multicolumn{2}{|c|}{56 species } & \multicolumn{2}{|c|}{62 species } \\
\hline$\%$ Similarity & & \multicolumn{2}{|c|}{$58.3-87.6$} & \multicolumn{2}{|c|}{$46.4-80.9$} \\
\hline Phytoplankton & Monthly & $27-45$ & $38 \pm 5$ & $33-45$ & $38 \pm 4$ \\
\hline Chlorophyta & Monthly & $20-35$ & $27 \pm 9$ & $24-34$ & $29 \pm 3$ \\
\hline \multicolumn{6}{|l|}{ Quantitative } \\
\hline Net Plankton & $\mathrm{n} / \mathrm{l}$ & $280-375$ & $335 \pm 26$ & $250-486$ & $352 \pm 74$ \\
\hline Phytoplankton & $\mathrm{n} / \mathrm{l}$ & $102-201$ & $155 \pm 30$ & $107-219$ & $154 \pm 32$ \\
\hline$\%$ composition & & $36.4-56.8$ & $46.0 \pm 6.3$ & $39.1-50.7$ & $43.8 \pm 3.0$ \\
\hline Species Diversity & & $3.008-3.574$ & $3.365 \pm 0.177$ & $3.208-3.584$ & $3.437 \pm 0.131$ \\
\hline Dominance & & $0.059-0.274$ & $0.127 \pm 0.059$ & $0.046-0.164$ & $0.086 \pm 0.032$ \\
\hline Evenness & & $0.864-0.976$ & $0.924 \pm 0.034$ & $0.917-0.970$ & $0.946 \pm 0.015$ \\
\hline Different Groups & & \multicolumn{4}{|c|}{ Chlorophyta $>$ Bacillariophyta } \\
\hline Chlorophyta & $\mathrm{n} / \mathrm{l}$ & $83-137$ & $115 \pm 22$ & $80-159$ & $114 \pm 23$ \\
\hline$\%$ composition & & $65.6-81.4$ & $74.6 \pm 5.2$ & $69.7-76.1$ & $74.2 \pm 2.7$ \\
\hline Bacillariophyta & $\mathrm{n} / \mathrm{l}$ & $13-49$ & $33 \pm 10$ & $21-45$ & $32 \pm 7$ \\
\hline$\%$ composition & & $12.7-29.3$ & $21.3 \pm 4.7$ & $16.8-25.4$ & $20.8 \pm 2.3$ \\
\hline Dinophyta & $\mathrm{n} / \mathrm{l}$ & $2-9$ & $4 \pm 2$ & $0-8$ & $3 \pm 3$ \\
\hline$\%$ composition & & $1.2-3.9$ & $2.7 \pm 1.1$ & $0-3.9$ & $2.0 \pm 1.0$ \\
\hline Euglenophyta & $n / 1$ & $0-7$ & $3 \pm 2$ & $1-7$ & $4 \pm 2$ \\
\hline$\%$ composition & & $0-3.8$ & $1.9 \pm 1.0$ & $0.9-4.1$ & $2.5 \pm 1.0$ \\
\hline Chrysophyta & $\mathrm{n} / \mathrm{l}$ & $0-1$ & - & $0-4$ & $2 \pm 1$ \\
\hline \multicolumn{6}{|l|}{ Important taxa } \\
\hline Closterium spp. & $\mathrm{n} / \mathrm{l}$ & $12-37$ & $27 \pm 5$ & $14-51$ & $29 \pm 5$ \\
\hline Staurastrum spp. & $\mathrm{n} / \mathrm{l}$ & $0-16$ & $9 \pm 4$ & $8-21$ & $13 \pm 4$ \\
\hline Gonatozygon spp & $\mathrm{n} / \mathrm{l}$ & $8-54$ & $26 \pm 4$ & $11-33$ & $18 \pm 7$ \\
\hline Micrasterias spp. & $\mathrm{n} / \mathrm{l}$ & $3-23$ & $12 \pm 7$ & $1-16$ & $10 \pm 5$ \\
\hline Cosmarium spp. & $\mathrm{n} / \mathrm{l}$ & $3-9$ & $6 \pm 3$ & $4-10$ & $7 \pm 2$ \\
\hline Xanthidium spp. & $\mathrm{n} / \mathrm{l}$ & $0-12$ & $6 \pm 4$ & $0-9$ & $5 \pm 3$ \\
\hline
\end{tabular}


Table 3. Temporal variations of Phytoplankton of Waithou Pat

\begin{tabular}{|c|c|c|c|c|c|}
\hline Parameters $\downarrow$ & Years $\rightarrow$ & \multicolumn{2}{|c|}{$2002-03$} & \multicolumn{2}{|c|}{ 2003-2004 } \\
\hline \multicolumn{2}{|l|}{ Qualitative } & \multicolumn{4}{|c|}{ Chlorophyta $>$ Bacillariophyta $>$ Dinophyta $>$ Euglenophyta $>$ Chrysophyta } \\
\hline Phytoplankton & Total & \multicolumn{2}{|c|}{61 species } & \multicolumn{2}{|c|}{60 species } \\
\hline \multicolumn{2}{|l|}{$\%$ Similarity } & \multicolumn{2}{|c|}{$66.7-95.0$} & \multicolumn{2}{|c|}{$55.6-85.4$} \\
\hline Phytoplankton & Monthly & $32-45$ & $39 \pm 4$ & $33-46$ & $40 \pm 4$ \\
\hline Chlorophyta & Monthly & $24-34$ & $28 \pm 3$ & $25-42$ & $28 \pm 2$ \\
\hline \multicolumn{6}{|l|}{ Quantitative } \\
\hline Net Plankton & $\mathrm{n} / \mathrm{l}$ & $286-446$ & $360 \pm 41$ & $338-611$ & $413 \pm 84$ \\
\hline Phytoplankton & $\mathrm{n} / \mathrm{l}$ & $105-210$ & $157 \pm 29$ & $115-251$ & $171 \pm 38$ \\
\hline \multicolumn{2}{|l|}{ \% composition } & $36.7-52.2$ & $43.4 \pm 4.3$ & $34.0-48.4$ & $41.5 \pm 4.2$ \\
\hline \multicolumn{2}{|l|}{ Species Diversity } & $3.272-3.627$ & $3.482 \pm 0.122$ & $3.370-3.691$ & $3.522 \pm 0.102$ \\
\hline \multicolumn{2}{|l|}{ Dominance } & $0.064-0.162$ & $0.101 \pm 0.028$ & $0.057-0.107$ & $0.078 \pm 0.012$ \\
\hline \multicolumn{2}{|l|}{ Evenness } & $0.917-0.992$ & $0.953 \pm 0.018$ & $0.920-0.973$ & $0.954 \pm 0.016$ \\
\hline \multicolumn{2}{|l|}{ Different Groups } & \multicolumn{4}{|c|}{ Chlorophyta > Bacillariophyta } \\
\hline Chlorophyta & $\mathrm{n} / \mathrm{l}$ & $83-139$ & $111 \pm 16$ & $85-164$ & $115 \pm 25$ \\
\hline \multicolumn{2}{|l|}{$\%$ composition } & $63.3-84.3$ & $71.7 \pm 6.2$ & $61.0-75.3$ & $67.5 \pm 4.8$ \\
\hline Bacillariophyta & $\mathrm{n} / \mathrm{l}$ & $14-51$ & $36 \pm 14$ & $21-55$ & $39 \pm 10$ \\
\hline \multicolumn{2}{|l|}{$\%$ composition } & $13.3-31.1$ & $22.1 \pm 5.9$ & $13.0-32.1$ & $23.0 \pm 4.7$ \\
\hline Dinophyta & $\mathrm{n} / \mathrm{l}$ & $0-4$ & $2 \pm 1$ & $0-9$ & $4 \pm 3$ \\
\hline \multicolumn{2}{|l|}{$\%$ composition } & $0-2.7$ & $1.0 \pm 0.8$ & $0-5.7$ & $2.1 \pm 1.8$ \\
\hline Euglenophyta & $\mathrm{n} / \mathrm{l}$ & $2-15$ & $6 \pm 3$ & $3-20$ & $10 \pm 5$ \\
\hline \multicolumn{2}{|l|}{$\%$ composition } & $1.2-7.4$ & $3.7 \pm 2.0$ & $1.9-8.0$ & $5.4 \pm 2.09$ \\
\hline Chrysophyta & $\mathrm{n} / \mathrm{l}$ & $0-4$ & $2 \pm 1$ & $0-6$ & $3 \pm 2$ \\
\hline \multicolumn{2}{|l|}{$\%$ composition } & $0-2.9$ & $1.4 \pm 1.0$ & $0-3.1$ & $1.6 \pm 1.1$ \\
\hline \multicolumn{6}{|l|}{ Important taxa } \\
\hline Closterium spp. & $\mathrm{n} / \mathrm{l}$ & $13-40$ & $23 \pm 8$ & $10-45$ & $23 \pm 8$ \\
\hline Staurastrum spp. & $\mathrm{n} / \mathrm{l}$ & $4-16$ & $10 \pm 4$ & $6-16$ & $11 \pm 4$ \\
\hline Gonatozygon spp & $\mathrm{n} / \mathrm{l}$ & $0-7$ & $2 \pm 2$ & $0-9$ & $4 \pm 3$ \\
\hline Micrasterias spp. & $\mathrm{n} / \mathrm{l}$ & $4-11$ & $8 \pm 2$ & $5-17$ & $9 \pm 4$ \\
\hline Cosmarium spp. & $\mathrm{n} / \mathrm{l}$ & $9-22$ & $14 \pm 4$ & $6-24$ & $15 \pm 5$ \\
\hline Xanthidium spp. & $\mathrm{n} / \mathrm{l}$ & $0-14$ & $10 \pm 5$ & $8-19$ & $9 \pm 4$ \\
\hline
\end{tabular}

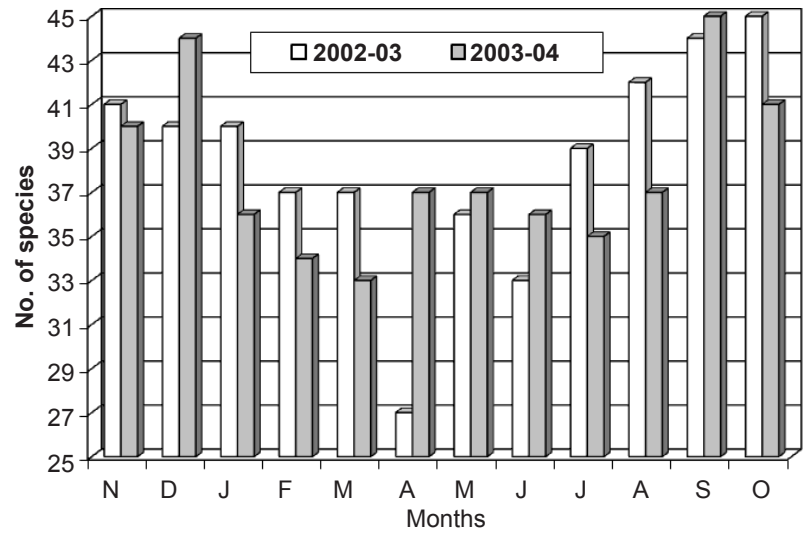

Figure 1. Monthly variations in species richness of phytoplankton of Utra Pat

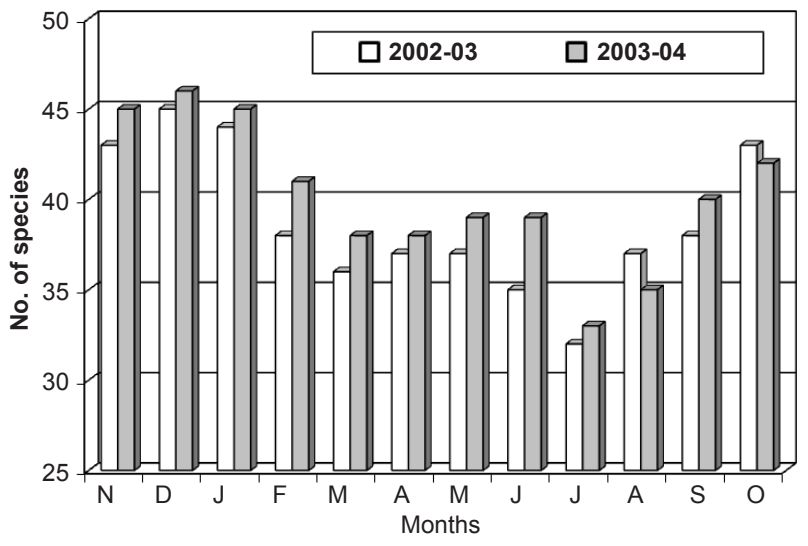

Figure 2. Monthly variations in species richness of phytoplankton of Waithou Pat 
concurs with the reports of Goswami \& Goswami (2001) and Sharma $(2009,2010)$ but differs from more diatom richness reported by Baruah et al. (1993) and Sharma (2004). Slightly acidic and Calcium-poor waters with low ionic concentrations (Payne 1986) are known to indicate greater desmid diversity. The water quality of the presently sampled pats affirms these interesting features.

Monthly phytoplankton richness records broadly concurrent variations in Utra $(27-45,38 \pm 4$ species) and Waithou (32-46, $39 \pm 4$ species) pats (Tables 2-3). Richness registers significant monthly variations $\left(F_{23}\right.$, ${ }_{47}=2.453, p=0.018$ ), indicates insignificant temporal variations between two pats. It registers significant monthly variations in Utra $\left(F_{11,23}=2.837, p=0.049\right)$ and Waithou $\left(F_{11,23}=23.780, p=4 E-06\right)$ pats individually but records significant annual variations in Waithou pat $\left(F_{1,23}=8.185\right.$, $p=0.015)$ only. The present study shows no definite periodicity of richness of phytoplankton in each pat (Figs. 1-2); this generalization concurs with the author's earlier remarks (Sharma 2004, 2009, 2010) in certain floodplain lakes of northeastern India. Richness inversely correlates with specific conductivity $\left(r_{1}=-0.524, P=0.0003\right)$ in Utra Pat; it inversely correlates with water temperature $\left(r_{2}=\right.$ $-0.675, p=0.0001)$, rainfall $\left(r_{2}=-0.670, p=0.0002\right), p H$ $\left(r_{2}=-0.474, P=0.0096\right)$, specific conductivity $\left(r_{2}=-0.475\right.$, $p=0.0096)$, nitrate $\left(r_{2}=-0.723, p<0.0001\right)$, chloride $\left(r_{2}=\right.$ $-0.710, p<0.0001)$ and total dissolved solids $\left(r_{2}=-0.811\right.$, $p<0.0001)$, and is positively correlated with dissolved organic matter $\left(r_{2}=0.536, p=0.0035\right)$ in Waithou Pat. Multiple regression registers relatively lower cumulative influence of fifteen abiotic factors on phytoplankton richness $\left(R_{1}^{2}=0.621\right)$ in Utra Pat but shows higher cumulative influence $\left(R_{2}^{2}=0.931\right)$ in Waithou Pat.

Chlorophyta richness in Utra (20-35, $29 \pm 4$ species) and Waithou (24-34, $28 \pm 3$ species) pats shows broadly identical variations during the study period (Tables 2-3), follows indefinite patterns of monthly variations identical to that of phytoplankton and significantly influences temporal variations of the latter $\left(r_{1}=0.877, p<0.0001\right.$ and $\left.r_{2}=0.959, p<0.0001\right)$. This group registers significant monthly variations $\left(F_{23,47}=3.750, p=0.001\right)$ and records insignificant temporal variations between two pats. In addition, the green algae register significant monthly variations of richness in Utra $\left(F_{11,23}=3.542, p=0.023\right)$ and Waithou $\left(F_{11,23}=5.743, p=0.004\right)$ pats individually. Chlorophyta richness inversely correlates with specific conductivity $\left(r_{1}=-0.601, p=0.0009\right)$ in Utra Pat while it inversely correlates with water temperature $\left(r_{2}=-0.468\right.$, $p=0.0105)$, rainfall $\left(r_{2}=-0.609, p=0.0008\right)$, specific conductivity $\left(r_{2}=-0.479, P=0.0089\right)$, nitrate $\left(r_{2}=-0.637\right.$, $p=0.0004)$, chloride $\left(r_{2}=-0.735, p<0.0001\right)$ and total dissolved solids $\left(r_{2}=-0.626, p=0.0005\right)$ in Waithou Pat. Multiple regression registers higher commutative influence $\left(R_{2}{ }^{2}=0.899\right)$ of 15 abiotic parameters on Chlorophyta richness in Waithou Pat than in $\left(R_{1}{ }^{2}=0.616\right)$ Utra Pat.

Phytoplankton communities of Utra and Waithou pats indicate between 58.3-87.6, 46.4-80.9 \% and 66.795.0, 55.6-85.4 \% similarities (vide Sorenson's index), respectively during two successive years. The similarity varies between $70-80 \%$ in majority of instances (59.1\%) in the matrix during 2002-03 and between $60-70 \%$ in $51.5 \%$ instances during 2003-04 in Utra Pat. Maximum instances $(63.3 \%)$ indicate $>90 \%$ similarity in Waithou Pat during 2002-03 while 57.6\% instances record similarity values between $70-80 \%$ in the following year. Hierarchical cluster analysis shows notable differences in annual clusters groupings in the sampled pats. In Utra Pat, highest similarities are observed amongst phytoplankton during September vs. October and December vs. September while February and April, and February and July communities exhibit more differences (Figs. 3-4) during two years respectively. Waithou Pat records higher similarities (Figs. 5-6) between February through June, August and again between September through October during 2002-03 as well as January and February during 2003-04. November and December samples differ most in their species composition in the first year while July and August collections differ more in the following year in Waithou Pat.

Phytoplankton abundance: Phytoplankton exhibit little quantitative differences between Utra (102-219, 154 $\pm 31 \mathrm{n} / \mathrm{l})$ and Waithou pats (105-251, $164 \pm 34 \mathrm{n} / \mathrm{l})$ during the study period (Tables 2-3). Abundance registers significant monthly variations $\left(F_{23,47}=3.566, p=0.002\right)$ and records insignificant temporal variations between two pats. Besides, it indicates significant monthly variations in Utra $\left(F_{11,23}=5.294, p=0.005\right)$ and Waithou $\left(F_{11,23}=\right.$ 4.847, $p=0.007$ ) pats but exhibits insignificant annual variations in each pat individually. Phytoplankton abundance in the sampled pats is marginally lower than that from Loktak Lake (Sharma 2009) and Deepor Beel (Sharma 2010) while it is distinctly lower than the reports from certain beels of West Bengal (Sugunan 1989; Vass 1989) and Bihar (Baruah et al. 1993; Sanjer \& Sharma 1995). Phytoplankton form a sub-dominant quantitative component of net plankton $(43.8 \pm 3.0 \%$ and $41.5 \pm 3.0$ $\%$ ) and, hence, concur with the reports of Sharma (2004, 2009, 2010) and Sharma \& Sharma (2008). Such a trend is in contrast to their dominance observed in certain floodplain lakes of Kashmir (Kaul \& Pandit 1982), Bihar (Rai \& Dutta-Munshi 1982; Baruah et al. 1993; Sinha et al. 1994; Sanjer \& Sharma 1995), West Bengal (Sugunan 1989) and Assam (Yadava et al. 1987; Goswami \& Goswami 2001). Further, significant positive correlation between abundance of phytoplankton vs. zooplankton ( $r_{1}$ $\left.=0.462, p=0.0115 ; r_{2}=0.641, p=0.0004\right)$ noticed in this study concurs with the reports of Yadava et al. (1987) and Sharma $(2004,2010)$ but differs from insignificant positive correlation between the two communities in Loktak (Sharma 2009).

This study follows no definite pattern of phytoplankton density variations except for relatively lower values 


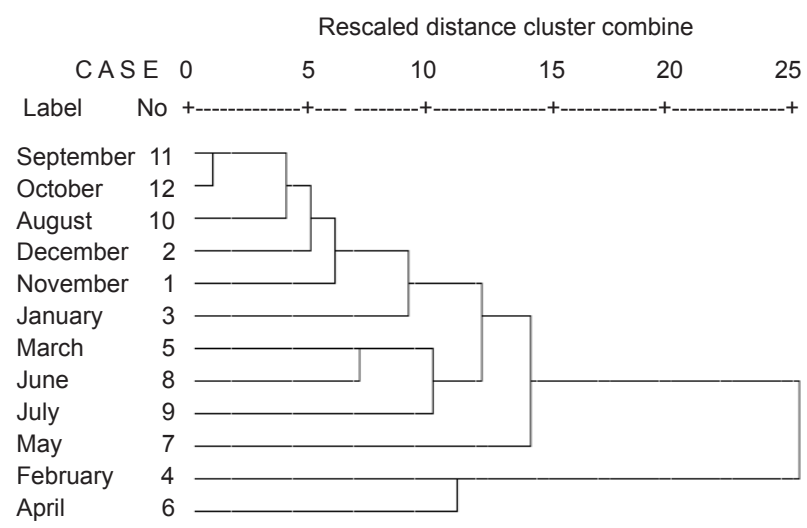

Figure 3. Hierarchical cluster analysis of phytoplankton of Utra Pat (2002-03)

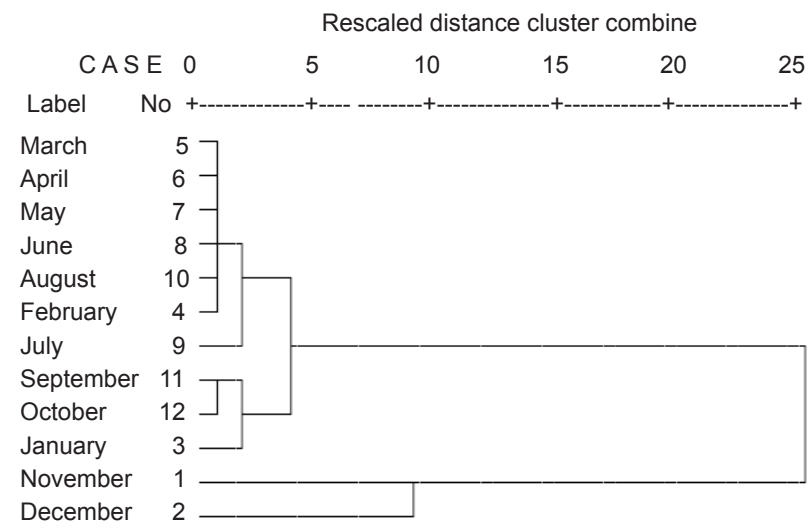

Figure 5. Hierarchical cluster analysis of Phytoplankton of Waithou Pat (2002-03)

during April-July and May-July in Utra and Waithou pats respectively (Figs. 7-8). The present results differ from trimodal pattern noticed in Loktak (Sharma 2009) and also from the bimodal variations reported by Yadava et al. (1987) and Sanjer \& Sharma (1995). In general, phytoplankton exhibit relatively higher abundance during periods of lower temperatures; this aspect is affirmed by their inverse correlation with water temperature $\left(r_{1}\right.$ $\left.=-0.686, P=0.0001 ; r_{2}=-0.575, p=0.0016\right)$ in both Utra and Waithou pats and also concurs with an identical report in Loktak (Sharma 2009). Besides, abundance inversely correlates with specific conductivity $\left(r_{1}=-0.691\right.$, $p<0.0001)$, free carbon dioxide $\left(r_{1}=-0.552, p=0.0022\right)$ and total dissolved solids $\left(r_{1}=-0.643, p=0.0003\right)$, and is positively correlated with alkalinity $\left(r_{1}=0.422, p=0.0200\right)$ in Utra Pat. On the other hand, it inversely correlates with rainfall $\left(r_{2}=-0.505, P=0.0009\right), \mathrm{pH}\left(r_{2}=-0.676, p\right.$ $=0.0001)$, nitrate $\left(r_{2}=-0.631, p=0.0005\right)$, chloride $\left(r_{2}=\right.$ $-0.514, p=0.0051)$ and total dissolved solids $\left(r_{2}=-0.640\right.$, $p=0.0004$ ) while it is positively correlated with dissolved organic matter $\left(r_{2}=0.668, p=0.0002\right)$ in Waithou Pat. In addition, fifteen abiotic factors exert higher cumulative influence $\left(R_{1}{ }^{2}=0.932, R_{2}{ }^{2}=0.929\right)$ on phytoplankton

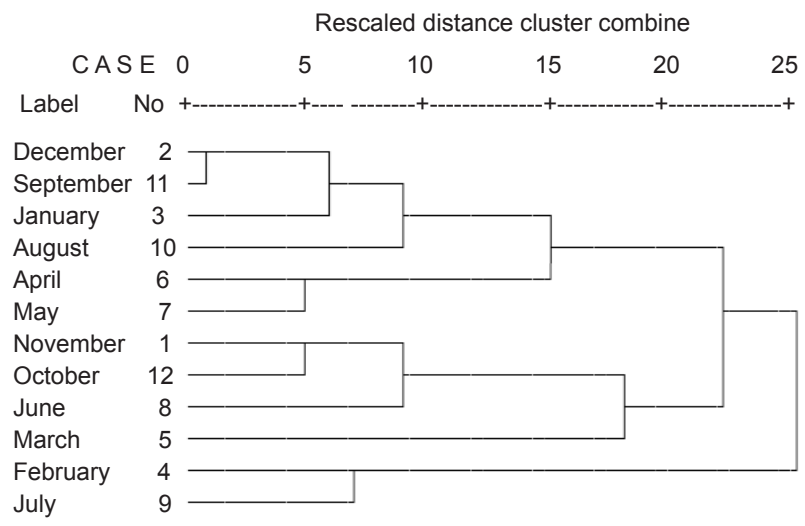

Figure 4. Hierarchical cluster analysis of Phytoplankton of Utra Pat (2003-04)

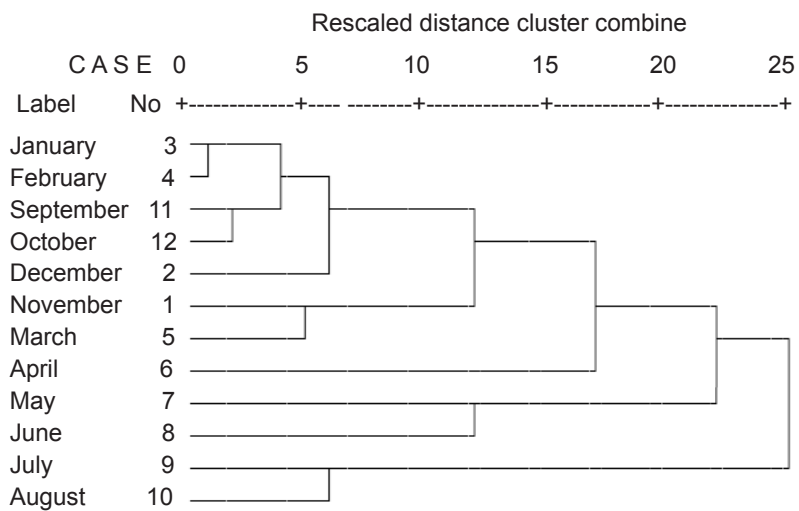

Figure 6. Hierarchical cluster analysis of Phytoplankton of Waithou Pat (2003-04)

abundance in the sampled pats.

Chlorophyta exhibit little differences in density variations between Utra $(80-159,114 \pm 23 \mathrm{n} / \mathrm{l})$ and Waithou $(83-164,113 \pm 21 \mathrm{n} / \mathrm{l})$ pats during this study (Tables 2-3). They comprise the dominant group (74.4 \pm $4.1 \%$ and $67.5 \pm 4.8 \%$ ) of phytoplankton of the two pats and distinctly influence temporal variations of the latter $\left(r_{1}=0.964, p<0.0001, r_{2}=0.920, p<0.0001\right)$. Their quantitative dominance concurs with the reports of Yadava et al. (1987), Choudhary \& Singh (2001), Goswami \& Goswami (2001) and Sharma $(2009,2010)$ but it differs from Bacillariophyta > Chlorophyta importance reported by Baruah et al. (1993) as well as from nearly equal importance of the two groups reported by Sharma (2004). The green algae register significant monthly variations $\left(F_{23,47}=4.047, p=0.0007\right)$ but show insignificant temporal variations between two pats. Further, this group indicates significant monthly variations in Utra $\left(F_{11,23}=4.228, p\right.$ $=0.012)$ and Waithou $\left(F_{11,23}=3.455, p=0.025\right)$ pats individually but exhibit insignificant annual variations in each pat.

Chlorophyta follow no definite annual pattern of quantitative variations except for relatively lower densities 


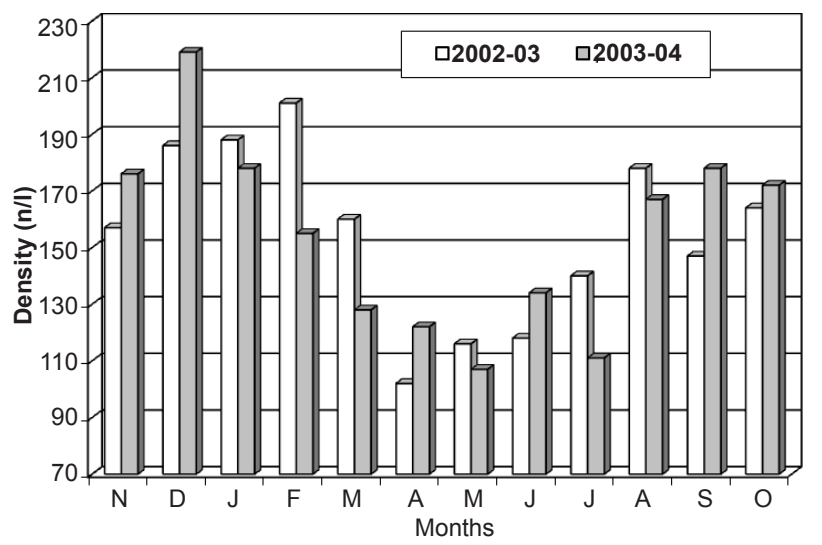

Figure 7. Monthly variations in abundance of phytoplankton of Utra Pat

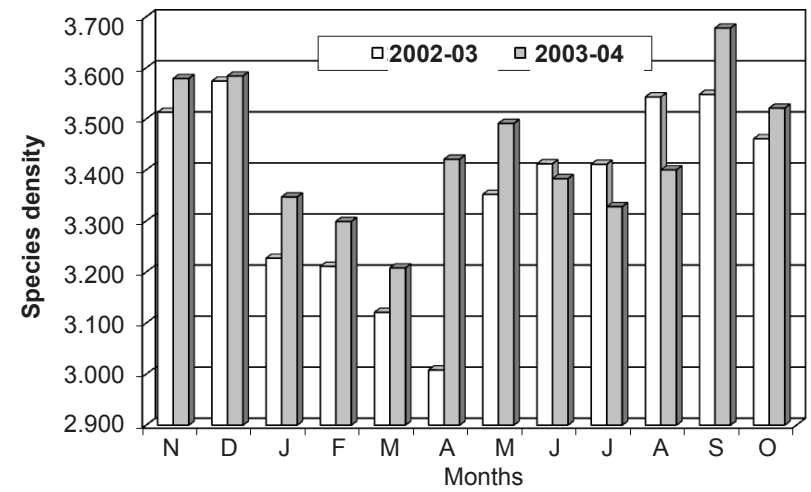

Figure 9. Monthly variations in species diversity of phytoplankton of Utra Pat

during April-July and May-July in Utra and Waithou pats respectively. Their abundance is notably higher than the earlier report of Sharma (2004) and it broadly corresponds with the results of Sharma $(2009,2010)$ while this group (the sole dominant component) distinctly forms higher percentage of phytoplankton than the stated earlier works. The green algae are characterized by importance of Closterium spp. $(28 \pm 9 \mathrm{n} / \mathrm{l})>$ Gonatozygon spp. $(21 \pm$ $10 \mathrm{n} / \mathrm{l})>$ Micrasterias spp. $(11 \pm 6 \mathrm{n} / \mathrm{l})>$ Staurastrum spp. $(11 \pm 6 \mathrm{n} / \mathrm{l})$ in Utra Pat and Closterium spp. $(23 \pm 9 \mathrm{n} / \mathrm{l})$ $>$ Cosmarium spp. $(14 \pm 5 \mathrm{n} / \mathrm{l})>$ Staurastrum spp. (11 $\pm 4 \mathrm{n} / \mathrm{l})>$ Xanthidium spp. $(10 \pm 4 \mathrm{n} / \mathrm{l})$ in Waithou Pat. In general, quantitative significance of various desmid taxa concurs with the results of Loktak Lake (Sharma 2009) but differs from lack of any such patterns noticed by Sharma $(2004,2010)$. Chlorophyta show relatively higher abundance during periods of lower temperatures; this feature is affirmed by their inverse correlation with water temperature $\left(r_{1}=-0.773, p<0.0001, r_{2}=-0.550\right.$, $p=0.0023$ ) in both pats and hence also concurs with an identical report in Loktak (Sharma 2009). In addition, their abundance inversely correlates with specific conductivity $\left(r_{1}=-0.614, p=0.0007\right), p H\left(r_{1}=-0.435, p\right.$

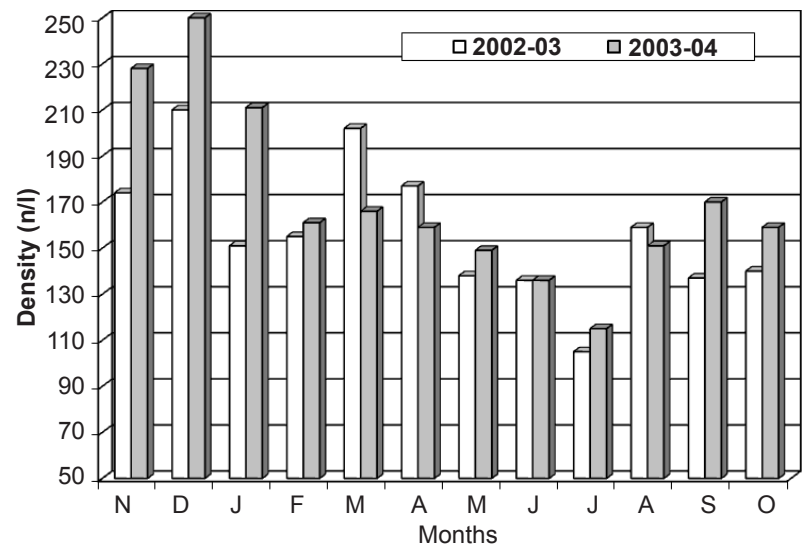

Figure 8. Monthly variations in abundance of phytoplankton of Waithou Pat

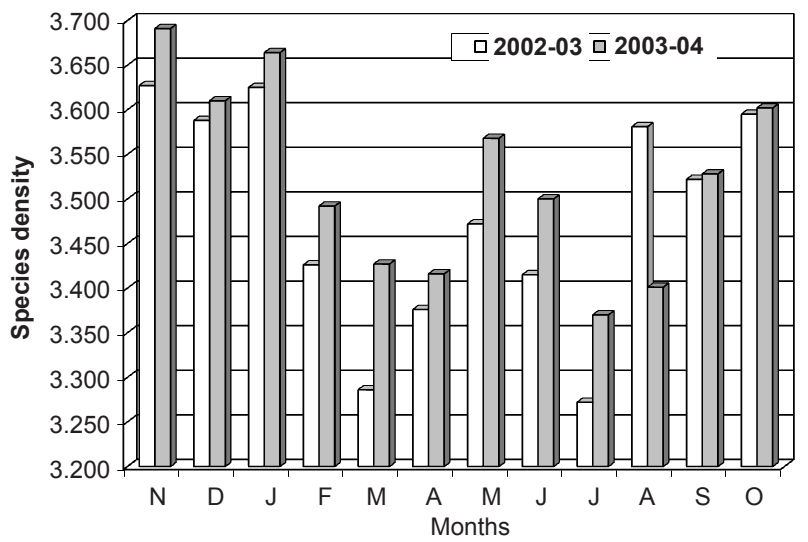

Figure 10. Monthly variations in species diversity of phytoplankton of Waithou Pat

$=0.0168)$, free carbon dioxide $\left(r_{1}=-0.601, p=0.0004\right)$ and total dissolved solids $\left(r_{1}=-0.689, p<0.0001\right)$ in Utra Pat; it is inversely correlated with rainfall $\left(r_{2}=-0.512, p=\right.$ $0.0053), \mathrm{pH}\left(r_{2}=-0.564, \mathrm{p}=0.0020\right)$, nitrate $\left(r_{2}=-0.597\right.$, $p=0.0010)$, chloride $\left(r_{2}=-0.586, p=0.0013\right)$ and total dissolved solids $\left(r_{2}=-0.563, p=0.0021\right)$ while it records positively correlation with dissolved organic matter $\left(r_{2}=\right.$ $0.549, p=0.0027$ ) in Waithou Pat. Besides, fifteen abiotic factors exert higher cumulative influence $\left(R_{1}{ }^{2}=0.927\right.$, $\mathrm{R}_{2}^{2}=0.870$ ) on Chlorophyta abundance in the two pats respectively.

Bacillariophyta (13-49, $32 \pm 9 \mathrm{n} / \mathrm{l}$ and 14-55, $37 \pm 12$ $\mathrm{n} / \mathrm{l}$ ) form the sole sub-dominant group (Tables 2-3) of phytoplankton ( $20.8 \pm 3.8$ and $22.6 \pm 5.3 \%$ ) and indicate little density differences with indefinite annual patterns in Utra and Waithou pats respectively. The present results differ from the sub-dominance of Dinophyta > Bacillariophyta observed in Loktak Lake (Sharma 2009) while it represents one of the dominant group in Deepor beel (Sharma 2010). This group registers insignificant monthly as well as temporal variations between the two pats. Further, the diatoms record significant monthly 
variations in Utra Pat $\left(F_{11,23}=3.170, p=0.034\right)$ only but exhibit insignificant annual variations in each pat. Bacillariophyta is inversely correlated with specific conductivity $\left(r_{1}=-0.631, p=0.0005\right)$ in Utra Pat while it inversely correlates with specific conductivity $\left(r_{2}=\right.$ $-0.583, p=0.0014)$ and total dissolved solids $\left(r_{2}=-0.487\right.$, $p=0.0079$ ), and is positively correlated with dissolved organic matter $\left(r_{2}=0.638, p=0.0004\right)$ in Waithou Pat. Fifteen abiotic factors exert higher cumulative influence $\left(R_{1}^{2}=0.822, R_{2}^{2}=0.805\right)$ on the diatom densities in the two pats.

Other groups of phytoplankton namely Dinophyta > Euglenophyta > Chrysophyta record very low densities in the sampled pats. This is in contrast to Dinophyta importance reported earlier by Sharma (2009, 2010). Further, this study lacks quantitative importance of any individual species of phytoplankton in Utra and Waithou pats as against significance of Ceratium hirudinella observed earlier in Loktak Lake (Sharma 2009) and Deepor Beel (Sharma 2010) from the floodplain lakes of northeastern India.

Species diversity, evenness and dominance: Phytoplankton is characterized by higher species diversity both in Utra (3.008 - 3.584, 3.401 \pm 0.161$)$ and (3.272 3.691, $3.502 \pm 0.114$ ) Waithou pats (Tables $2 \& 3$ ), and register significant monthly variations $\left(F_{23,47}=3.227, p=\right.$ 0.003 ) as well as significant temporal variations between two pats $\left(F_{1,47}=12.997, p=0.001\right)$. In addition, diversity exhibits significant monthly $\left(F_{11,23}=4.489, p=0.009\right)$ in Utra Pat and also records significant monthly variations $\left(F_{11,23}\right.$ $=7.535, p=0.001$ ) Waithou Pat. It registers indefinite annual and monthly patterns in individual pats (Figs. 9-10) which, in turn, concurs with the results in Loktak Lake (Sharma 2009) and Deepor Beel (Sharma 2010). In general, this study indicates higher species diversity than the report from Samuajan beel (Sharma, 2004) while mean values are marginally higher than the report from Deepor Beel (Sharma 2010) but broadly concur with those of Loktak Lake (Sharma 2009). Species diversity is positively correlated with richness of Phytoplankton $\left(r_{1}=\right.$ $\left.0.768, p<0.0001 ; r_{2}=0.874, p<0.0001\right)$ and Chlorophyta $\left(r_{1}=0.772, p<0.0001 ; r_{2}=0.882, p<0.0001\right)$ in the two pats while it inversely correlates with abundance of phytoplankton $\left(r_{2}=-0.471, p=0.0101\right)$ and of Chlorophyta $\left(r_{2}=-0.468, p=0.0105\right)$ in Waithou Pat only.

The present results indicate consistently higher phytoplankton evenness with broadly identical values (0.917 - 0.970, $0.946 \pm 0.015 ; 0.917-992,0.953 \pm 0.017)$ in Utra and Waithou pats, respectively (Tables 2 \& 3). It follows indefinite annual and monthly patterns in individual pats, and registers significant monthly variations $\left(\mathrm{F}_{23,47}=\right.$ 2.108, $p=0.040$ ) as well as significant temporal variations $\left(F_{1,47}=10.785, p=0.003\right)$ between two pats. Besides, this study indicates significant annual $\left(F_{1,23}=6.569, p=\right.$ 0.026 ) and insignificant monthly variations of evenness in Utra Pat while it depicts only significant monthly variations
$\left(F_{11,23}=3.117, p=0.036\right)$ in Waithou Pat. Higher evenness concurs with the results of Sharma (2004, 2009, 2010). The results reflect equitable abundance of various species throughout the study period and, hence, deviate a little from relatively lower winter evenness noticed in Loktak Lake (Sharma 2009). Evenness is inversely correlated with species diversity $\left(r_{2}=-0.651, p=0.0003\right)$ in Waithou Pat while it records insignificant inverse correlation with the latter in Utra Pat.

Phytoplankton indicate lower dominance with broadly concurrent values $(0.046-0.274,0.107 \pm 0.031 ; 0.057$ $0.162,0.089 \pm 0.025)$ in Utra and Waithou pats, respectively (Tables 2 -3) which re-affirm lack of quantitative importance of individual species. Dominance registers insignificant annual and monthly variations between two pats but it records significant annual variations individually in $U$ tra $\left(F_{1}\right.$, $\left.{ }_{23}=6.419, p=0.028\right)$ and Waithou $\left(F_{1,23}=9.621, p=0.010\right)$ pats. Further, it is positively correlated with phytoplankton species diversity $\left(r_{1}=0.744, P<0.0001 ; r_{2}=0.452, p=\right.$ $0.0135)$ while it records insignificant inverse correlations with their evenness in the two pats. The salient feature of low dominance though broadly corresponds with the reports of Sharma $(2004,2009,2010)$.

To sum up, phytoplankton communities of Utra and Waithou pats are fairly speciose and are characterized by distinct qualitative and quantitative importance of Chlorophyta in general and the desmids in particular. Phytoplankton and its important constituent groups reflect lack of definite periodicity of richness and abundance. Chlorophyta show quantitative dominance, Bacillariophyta is a sub-dominant group while other groups record very lower densities. Phytoplankton is characterized by higher diversity, lower dominance and higher evenness with indefinite patterns of annual and monthly variations. Individual abiotic factors depict little or limited influence on richness and abundance of phytoplankton but register higher cumulative influence.

\section{REFERENCES}

Adoni, A.D., G. Ghosh, S.K. Chourasia, A.K. Vaishya, M. Yadav \& H.G. Verma (1985). Workbook on Limnology. Pratibha Publishers, 216pp.

APHA (1992). Standard Methods for the Examination of Water and Waste Water (18th edition). American water Works Association and Water Pollution Control Federation, New York, 1198pp.

Baruah, A., A.K. Sinha \& U.P. Sharma (1993). Plankton variability of a tropical wetland, Kawar (Begusarai), Bihar. Journal of Freshwater Biology 5: 27-32.

Choudhary, S. \& D.K. Singh (2001). Phytoplankton population of Boosra Lake (Gaighat block, Muzaffarpur, Bihar). Environment \& Ecology 19: 171-174.

Fritter, R. \& R. Manuel (1986). Field Guide to The Freshwater Life of Britain and North-West Europe. William Collins Sons \& Co. Ltd, London, 382pp.

Goswami, M.M. \& N. Goswami (2001). Studies on productivity indicators in Mori Beel of Assam. Tropical Zoology 2 \& 3: $1-9$. 
Islam, A.K.M.N. \& A.K.Y. Haroon (1980). Desmids of Bangladesh. Internationale Revue gesammten Hydrobiologie 65(4): 551-604.

Kaul, V. \& A.K. Pandit (1982). Biotic factors and food chain structure in some typical wetlands of Kashmir. Pollution Research 1: 49-54.

Ludwig, J.A. \& J.F. Reynolds (1988). Statistical Ecology: A Primer on Methods and Computing. John Wiley \& Sons, New York, 337pp.

Magurran, A.E. (1988). Ecological Diversity and Its Measurement. Croom Helm Limited, London, 179pp.

Needham, J.G. \& P.R. Needham (1962). A Guide to the study of Freshwater Biology. Holden-Day, Inc., San Francisco, $108 p$.

Payne, A.R. (1986). The Ecology of Tropical Lakes and Rivers. John Wiley \& Sons, New York, 301pp.

Rai, D.N. \& J.M. Dutta-Munshi (1982). Ecological characteristics of 'Chaurs' of north Bihar, pp. 89-95. In: Gopal, B., R.E. Turner, R.G. Wetzel \& D.F. Winghon (eds.). Wetlands Ecology and Management, Vol. II. International Scientific Publications and National Institute of Ecology, Jaipur, India.

Sanjer, L.R. \& U.P. Sharma (1995). Community structure of plankton in Kawar lake wetland, Begusarai, Bihar: I Zooplankton. Journal of Freshwater Biology 7: 165-167.

Sharma, B.K. (2004). Phytoplankton communities of a floodplain lake of the Brahmaputra river basin, Upper Assam. Journal of the Indian Fisheries Association 31: 27-35.
Sharma, B.K. (2009). Composition, abundance and ecology of phytoplankton communities of Loktak Lake, Manipur, India. Journal of Threatened Taxa 1(8): 401-410.

Sharma, B.K. (2010). Phytoplankton communities of Deepor beel (a Ramsar site), Assam (N. E. India): composition and ecology. In: Barik, S.K. (ed.). Ecosystem and Plant diversity. Regency Publications, New Delhi (in press).

Sinha, A.K., A. Baruah, D.K. Singh \& U.P. Sharma (1994). Biodiversity and pollution status in relation to physicochemical factors of Kawar lake (Begusarai), North Bihar. Journal of Freshwater Biology 6: 309-331.

Sugunan, V.V. (1989). Limnological features in beels: Biotic factors. Bulletin Central Inland Capture Fisheries Research Institute, Barrackpore 63: 128-135.

Talling. J.F. \& I.B. Talling (1965). The chemical composition of African lake waters. Internationale Revue gesammten Hydrobiologie 50: 421-463.

Vass, K.K. (1989). Beel fisheries resources in West Bengal. Bulletin Central Inland Capture Fisheries Research Institute, Barrackpore 63: 29-35.

Yadava, Y.S., R.K. Singh, M. Choudhury \& V. Kolekar (1987). Limnology and productivity in Dighali beel (Assam). Tropical Ecology 28: 137-146. 